\title{
The combination of Radix Astragali and Radix Angelicae Sinensis attenuates the IFN- $\gamma$-induced immune destruction of hematopoiesis in bone marrow cells
}

Juan Liu', Jie Wei ${ }^{1}$, Changzhi Wang ${ }^{1}$, Xiaoying Meng ${ }^{1}$, Hening Chen ${ }^{1}$, Peiying Deng ${ }^{1}$, Meiyier Huandike ${ }^{1}$, Huijie Zhang ${ }^{1}$, Xue Li ${ }^{2}$ and Limin Chai ${ }^{*}$

\begin{abstract}
Background: Radix Astragali and Radix Angelicae Sinensis are two herbs that compose Danggui Buxue Tang (an herbal formula for treatment of anemia diseases). In this study, we explored the molecular mechanism and effective targets to immune destruction of bone marrow (BM) cells treated with Radix Astragali, Radix Angelicae Sinensis or a combination of two agents. The potential synergic advantages of two herbs should also be explored.

Methods: The constituents of Radix Astragali and Radix Angelicae Sinensis were analyzed by high performance liquid chromatography-electrospray ionization/mass spectrometer system BM cells were separated from limbs of BALB/C mice, and immune destruction was induced with IFN- - . The percentages of hematopoietic stem cells (HSCs) and $\mathrm{CD}^{+} \mathrm{T}$ cells were detected by flow cytometry. The distribution of T-bet and changes in the combination of SAP and SLAM in BM cells were observed by immunofluorescence. Western blotting was used to assay the expression of key molecules of the elF2 signaling pathway in BM cells.

Results: Seven constituents of Radix Astragali and six constituents of Radix Angelicae Sinensis were identified. The percentages of HSCs increased significantly after treatment with Radix Angelicae Sinensis, especially at high concentrations. The percentages of $\mathrm{CD}^{+} \mathrm{T}$ cells were significantly decreased after Radix Astragali and Radix Angelicae Sinensis treatment. However, the synergistic function of two-herb combinations was superior to that of the individual herbs alone. The distribution of T-bet in BM cells was decreased significantly after Radix Angelicae Sinensis treatment. The number of SLAM/SAP double-stained cells was increased significantly after Radix Astragali treatment at low concentrations. The phosphorylation levels of elF2a were also reduced after Radix Astragali and Radix Angelicae Sinensis treatment.

Conclusions: Radix Astragali and Radix Angelicae Sinensis could intervene in the immunologic balance of T lymphocytes, inhibit the apoptosis of BM cells induced by immune attack, restore the balance of the T cell immune response network and recover the hematopoietic function of HSCs. The synergistic effects of Radix Astragali and Radix Angelicae Sinensis were superior to those of each herb alone.
\end{abstract}

Keywords: Radix Astragali, Radix Angelicae Sinensis, Immune destruction, Apoptosis, Bone marrow cell

\footnotetext{
* Correspondence: liminchai@hotmail.com

${ }^{1}$ Key Laboratory of Chinese Internal Medicine of Ministry of Education and

Beijing, Dongzhimen Hospital, Beijing University of Chinese Medicine,

Haiyuncang Hutong No.5, Dongcheng District, Beijing, China

Full list of author information is available at the end of the article
}

(c) The Author(s). 2019 Open Access This article is distributed under the terms of the Creative Commons Attribution 4.0 International License (http://creativecommons.org/licenses/by/4.0/) which permits unrestricted use, distribution, and reproduction in any medium, provided you give appropriate credit to the original author(s) and the source, provide a link to the Creative Commons license, and indicate if changes were made. The Creative Commons Public Domain Dedication waiver (http://creativecommons.org/publicdomain/zero/1.0/) applies to the data made available in this article, unless otherwise stated. 


\section{Background}

The pathophysiology of unusual hematologic diseases is immune mediated with activated type I cytotoxic T cells; that express $\mathrm{T}$ cell-specific cytokines, especially $\gamma$ interferon (IFN- $\gamma$ ). Immune attack leading to bone marrow failure by $\mathrm{T}$ cells can be imitated in vitro. IFN- $\gamma$ is an important cytokine in orchestrating a vast array of immunologic responses and is also known as a suppressor of hematopoiesis [1]. Several studies have confirmed that IFN- $\gamma$ can induce apoptosis of hematopoietic stem cells (HSCs), partially through the Fas-dependent apoptotic pathway. Bone marrow (BM) failure in multiple chronic inflammatory diseases is associated with increased IFN- $\gamma$ levels in the bone microenvironment [2, $3]$. IFN- $\gamma$ can also regulate the physiological function of interferon regulatory factor 1 (IRF-1), inhibit the transcription of cellular genes, and contribute to attenuating the cell cycle of BM cells [4].

Herbal partners through clinical application are based on an affirmance theory foundation and compounding prescript of Chinese traditional medicine. Radix Astragali and Radix Angelicae Sinensis are a classic pair of available herbs in Chinese medicine for clinical anemia treatment [5-8]. Pharmacological studies indicated that Radix Angelicae Sinensis could be used to invigorate the blood circulation, and modulate the balance of the immune system in menstrual disorders, [9]. Several studies indicated that Radix Astragali has therapeutic functions including immunostimulation [10], hepatoprotection [11], anti-diabetic effects [12], analgesia [13] and sedation [14]. In addition, Danggui Buxue Tang (DBT, a classic Chinese herbal formula consisting of Radix Astragali and Radix Angelicae Sinensis) could promote hematopoietic function, stimulate cardiovascular circulation, prevent osteoporosis and has antioxidative functions [15-17]. Our previous studies have verified the hematopoietic function of modified DBT in anaplastic anemia mouse model by bone marrow suppression. The results indicated that modified DBT could decrease the proliferation and differentiation of effector $\mathrm{T}$ cells, impair Treg-mediated immunosuppressive functions, attenuate immune-mediated destruction of HSCs, repair hematopoietic failure and recover the hematopoietic function of HSCs in vivo [18, 19].

Based on the in vivo results, we wanted to investigate the functional mechanism of Radix Astragali, Radix Angelicae Sinensis or the two drugs together on immunosuppressive effects. BM cells induced by increasing doses of IFN- $\gamma$ were used as a cell model of immune destruction [20]. Radix Astragali, Radix Angelicae Sinensis or the combination of the two herbs was used to intervene in IFN- $\gamma$-induced immune destruction of hematopoiesis of BM cells. We wanted to study the specific cellular and protein targets of the immunosuppressive and hematopoietic functions of Radix Astragali and Radix Angelicae Sinensis on immune- attacked BM cells, and then probe the potential synergic mechanism of the combination of the two herbs. In this study, we used innovative in vitro experiments to verify the synergistic effect of this Chinese herbal formula.

\section{Methods}

Preparation of freeze-dried Radix Astragali and Radix Angelicae Sinensis water extract

Radix Astragali (Root pieces, Lot No. 19042102, origin: Inner Mongolia, China) and Radix Angelicae Sinensis (Root pieces, Lot No. 19050802, origin: Gansu, China), were purchased from Beijing Xidan Pharmaceutical Co., Ltd., China. Dr. Jie Wei, a senior Chinese medicine appraiser, undertook the formal identification of the herbs. The herbal inspection reports are shown in Additional file 1. We prepared aqueous extracts of the two herbs separately. A total of $200 \mathrm{~g}$ of raw herbal pieces was boiled in a $6 \times$ volume of water for $30 \mathrm{~min}$. The aqueous extract solution was concentrated to a volume of 100 $\mathrm{mL}$. Finally, the extract solution was filtered using a standard test sieve of $150 \mu \mathrm{m}$, freeze-dried and maintained in desiccators at $4{ }^{\circ} \mathrm{C}$ until use $[21,22]$.

\section{High-performance liquid chromatography-electrospray ionization/ mass spectrometer (HPLC-ESI/MS ${ }^{\mathrm{n}}$ ) analysis}

The freeze-dried powders of Radix Astragali and Radix Angelicae Sinensis water extracts were used for component analysis. The constituents of these two herbs were measured by HPLC-ESI/MS ${ }^{\mathrm{n}}$. The specific measurement procedures were previously described [23].

\section{Obtaining mouse BM cells}

Female BALB/c mice (Protocol No. SCKK (Jing) 2016006) were purchased from HFK Bioscience Co. Ltd. (Beijing, China). All animals were kept under standard lighting conditions ( $12 \mathrm{~h}$ alternating day and night cycles) and given free access to food and water. Animal experiments were performed according to protocols complied with ethical regulations and approved by the National Institute of State Scientific and Technological Commission.

Single-cell suspensions of bone marrow were isolated and cultured. Briefly, eight-week-old female mice were sacrificed by pentobarbital anesthesia $(1 \%, 45 \mathrm{mg} / \mathrm{kg})$. The tibias and femurs were collected in a sterile environment, and the ends of the long bones were trimmed to expose the interior marrow shaft. Bone marrow cells were rinsed with RPMI-1640 (Thermo Fisher Scientific Inc., Waltham, MA, USA) medium supplemented with 10\% FBS (Gibco, Grand Island, NY). To make a singlecell suspension, the were gently drawn up and down with a 3-cc syringe with a 21-g needle, filtered through a 
70-mm filter mesh, washed and resuspended. Cells were incubated at $37^{\circ} \mathrm{C}$ in a $5 \% \mathrm{CO}_{2}$ incubator [24].

\section{Cell viability assay}

BM cells taken from mice were plated and cultured in a 96-well plate $\left(1 \times 10^{5}\right.$ cells/well $)$ in RPMI-1640 supplemented with $10 \%$ FBS, Various concentrations of the water extract freeze-dried powders of Radix Astragali or Radix Angelicae Sinensis (0, 10, 50, 100, 250, 500, 750 and $1000 \mu \mathrm{g} / \mathrm{mL}$ ) were added to the medium, and incubated at $37^{\circ} \mathrm{C}$ in a humidified $5 \% \mathrm{CO}_{2}$ incubator. After $24 \mathrm{~h}$ of incubation, cell viability was determined by a Cell Counting Kit-8 (CCK-8) assay according to the manufacturer's instructions. BM cells $\left(1 \times 10^{4} /\right.$ well $)$ were seeded into a 96-well plate and incubated overnight in the previously described conditions. Then, the medium was removed, and the cells were washed twice with PBS.
Medium $(90 \mu \mathrm{L})$ and CCK-8 $(10 \mu \mathrm{L})$ were subsequently added to each well and incubated for $2 \mathrm{~h}$ at $37^{\circ} \mathrm{C}$. The optical density (OD value) of the cells was measured by a microplate reader (Model 3550 Microplate Reader, Bio-Rad Laboratories, Inc., Hercules, CA, USA) at a wavelength of $570 \mathrm{~nm}$ [25]. All experiments were performed in triplicate. The results of the CCK- 8 assay indicated that $100 \mu \mathrm{g} / \mathrm{mL}$ and $250 \mu \mathrm{g} / \mathrm{mL}$ were suitable concentrations for drug stimulation (Additional file 2: Fig. S1).

\section{Cell treatments}

BM cells were seeded in 6-well plates $\left(1 \times 10^{6}\right.$ cells/well $)$ or 24-well plates $\left(1 \times 10^{5}\right.$ cells/well $)$, and divided into following groups: Normal group ( $\mathrm{N}$ group), incubated in RPMI-1640 containing 10\% FBS; Model group (M group), incubated in RPMI-1640 containing 10\% FBS
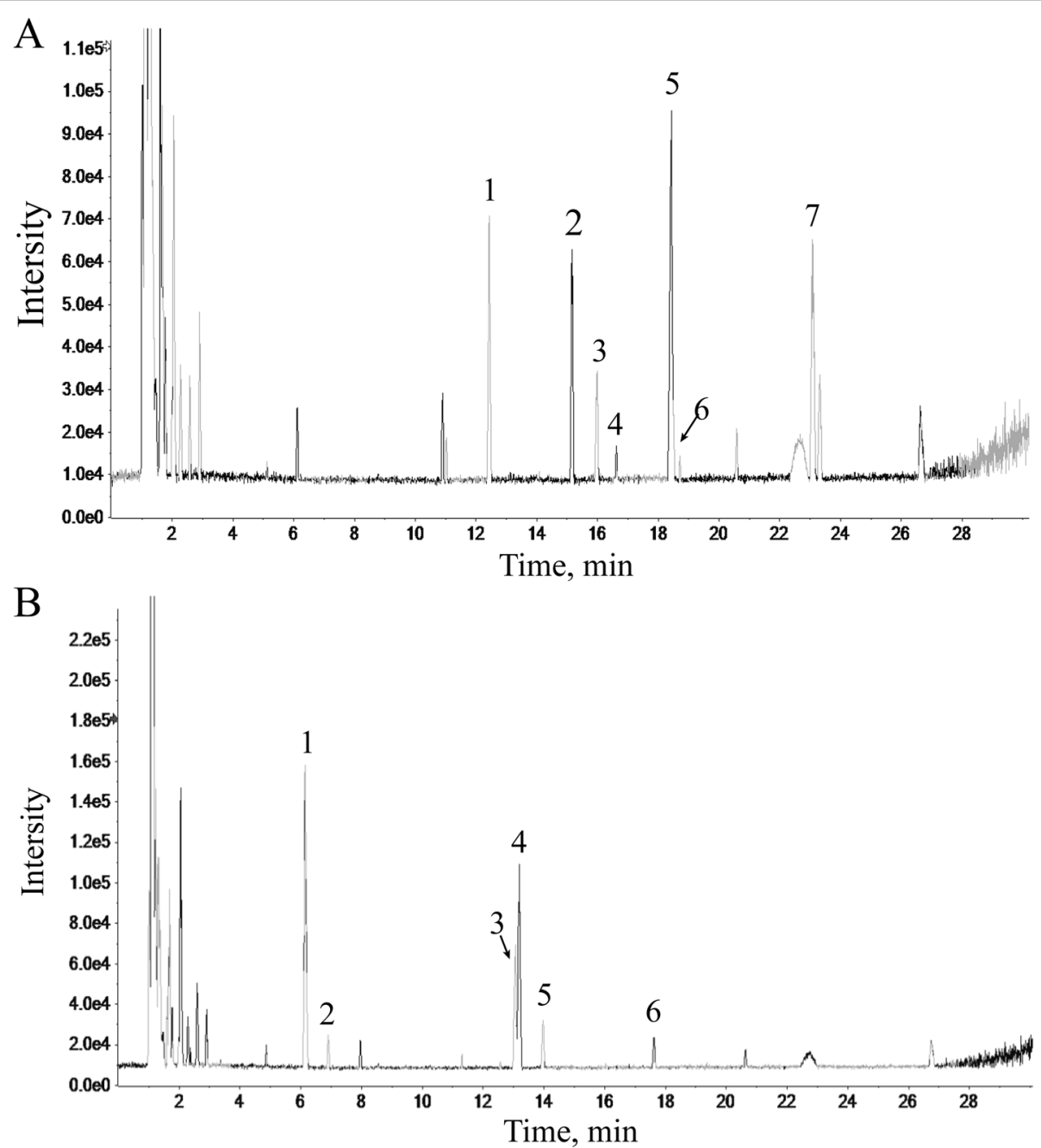

Fig. $1 \mathrm{HPLC}-\mathrm{ESI} / \mathrm{MS}^{\mathrm{n}}$ base peak chromatogram of the total ion chromatogram for the lyophilized powder of Radix Astragali and Radix Angelicae Sinensis aqueous extract. The abscissa represents the retention time, and the ordinate represents the chromatographic peak intensity. (a) HPLCESI/MS ${ }^{n}$ analysis of Radix Astragali. (b) HPLC-ESI/MS ${ }^{n}$ analysis of Radix Angelicae Sinensis 
Table 1 Chemical components identified from Radix Astragali by HPLC-ESI/MS ${ }^{n}$

\begin{tabular}{|c|c|c|}
\hline Peak & $t_{R}(\min )$ & Identification \\
\hline 1 & 12.437 & Calycosin-7-O- $\beta$-D-glucoside \\
\hline 2 & 15.161 & Calycosin-7-O- $\beta-D-$ glucoside-6"-O-malonate \\
\hline 3 & 15.979 & Ononin \\
\hline 4 & 16.624 & (6aR,-11aR)-3-Hydroxy-9,10-dimethoxypterocarpan-3-O- $\beta$-D-glucoside \\
\hline 5 & 18.416 & Calycosin \\
\hline 6 & 18.498 & Formononetin-7-O- $\beta-D-g l u c o s i d e-6 "-0-$ malonate \\
\hline 7 & 23.087 & Formononetin \\
\hline
\end{tabular}

with IFN- $\gamma(10 \mathrm{ng} / \mathrm{mL})$ (R\&D systems, USA); Radix Astragali group ( $\mathrm{R}$ group), incubated in RPMI-1640 containing $10 \%$ FBS with IFN- $\gamma(10 \mathrm{ng} / \mathrm{mL})$ and freeze-dried powder (Radix Astragali) $(100 \mu \mathrm{g} / \mathrm{mL}$ or $250 \mu \mathrm{g} / \mathrm{mL})$; Radix Angelicae Sinensis group (A group), incubated in RPMI-1640 containing 10\% FBS with IFN- $\gamma(10 \mathrm{ng} / \mathrm{mL})$ and freeze-dried powder (Radix Angelicae Sinensis) $(100 \mu \mathrm{g} / \mathrm{mL}$ or $250 \mu \mathrm{g} / \mathrm{mL})$; and the two-herb combination group ( $\mathrm{R}+\mathrm{A}$ group), incubated in RPMI-1640 containing $10 \%$ FBS with IFN- $\gamma(10 \mathrm{ng} / \mathrm{mL})$ and freeze-dried powders (Radix Astragali and Radix Angelicae Sinensis) $(100 \mu \mathrm{g} / \mathrm{mL}$ or $250 \mu \mathrm{g} / \mathrm{mL}$ each). After $12 \mathrm{~h}$ or $24 \mathrm{~h}$ of incubation, the cells were harvested.

\section{Flow cytometry analysis}

To quantify the percentage of hematopoietic stem cells (HSCs), BM cells $\left(1 \times 10^{5}\right.$ cells $)$ were stained with antimouse CD117 (c-Kit) FITC and anti-mouse Ly-6A/E (Sca-1) PE antibodies (eBioscience, San Diego, CA, USA). The percentages of $\mathrm{CD}^{+} \mathrm{CD}^{+}$(helper $\mathrm{T}$ cell, Th) and $\mathrm{CD}^{+} \mathrm{CD}^{+}$(cytotoxic $\mathrm{T}$ cell, CTL) lymphocytes were also measured. After $12 \mathrm{~h}$ or $24 \mathrm{~h}$ of treatment, BM cells were harvested and stained with anti-mouse CD3 PE-Cyanine7, CD4 PE-Cyanine5 and CD8a PE antibodies (eBioscience, San Diego, CA, USA). The percentages of staining cells were counted and analyzed by FACS Calibur cytometer and CellQuest software (Beckman Coulter, Brea, CA, USA). Each experiment was performed in triplicate with three replicates each.

Table 2 Chemical components identified from Radix Angelicae Sinensis by HPLC-ESI/MS ${ }^{n}$

\begin{tabular}{lll}
\hline Peak & $\mathrm{t}_{\mathrm{R}}(\mathrm{min})$ & Identification \\
\hline 1 & 6.14 & L-tryptophan \\
2 & 6.909 & Vanillic acid \\
3 & 13.06 & Ferulic acid \\
4 & 13.2 & Senkyunolide I \\
5 & 13.973 & Senkyunolide H \\
6 & 17.623 & Z (or E)-Butylidenephthalide \\
\hline
\end{tabular}

\section{Immunofluorescence staining}

After $12 \mathrm{~h}$ or $24 \mathrm{~h}$ of treatment, BM cells were collected. Cells $\left(0.5 \times 10^{4}\right.$ cells/well $)$ were planted in special petri dish for laser confocal microscope, and then incubated with anti- mouse T-bet PE (1:100) (eBioscience). In addition, the other portion of the BM cells was stained with anti-mouse CD150/SLAM PE antibody (1:50) (eBioscience). Cells were stained with SH2D1A/SAP antibody (FITC) (1:100) (EterLife, Birmingham, UK) after permeabilization. A Leitz/Leica TCSSP2 microscope (Leica Lasertechnik GmbH, Heidelberg, Germany) wasused to capture the fluorescence microscopy images. The fluorescence intensity was analyzed by ImageJ software. Each experiment was performed in triplicate with three replicates each.

\section{Western blotting analysis}

After $12 \mathrm{~h}$ or $24 \mathrm{~h}$ of treatment, BM cells $\left(1 \times 10^{6}\right.$ cells $)$ were washed three times with PBS and collected in RIPA lysis buffer. Total proteins were separated by $10 \%$ sodium dodecyl sulfate (SDS)-polyacrylamide gel electrophoresis (PAGE) and transferred onto nitrocellulose membranes (Amersham Pharmacia Biotech, Uppsala, Sweden). Specific antibodies were used to measure the levels of proteins, including anti-mouse eIF2 $\alpha$ and phospho-eIF2 $\alpha$ rabbit monoclonal antibodies (1:1000) (CST, Boston, MA, USA). The nitrocellulose membranes were incubated with specific antibodies at $4{ }^{\circ} \mathrm{C}$ overnight. Next, the membranes were incubated with a horseradish peroxidase-conjugated secondary antibody (CST). Immunoreactive proteins were visualized by the enhanced ECL method (Amersham Biosciences, Marlborough, $\mathrm{MA})$, and $\beta$-actin was used as an internal control. Each experiment was performed in triplicate with three replicates each. Densitometry values were quantified for each band using Image-Pro Plus version 4.0 (Media Cybernetics, Rockville, MD, USA).

\section{Statistical analysis}

All data are presented as the mean \pm standard deviation (SD) of the mean from at least three independent experiments. GraphPad Prism 5.0 and SPSS version 13.0 were 

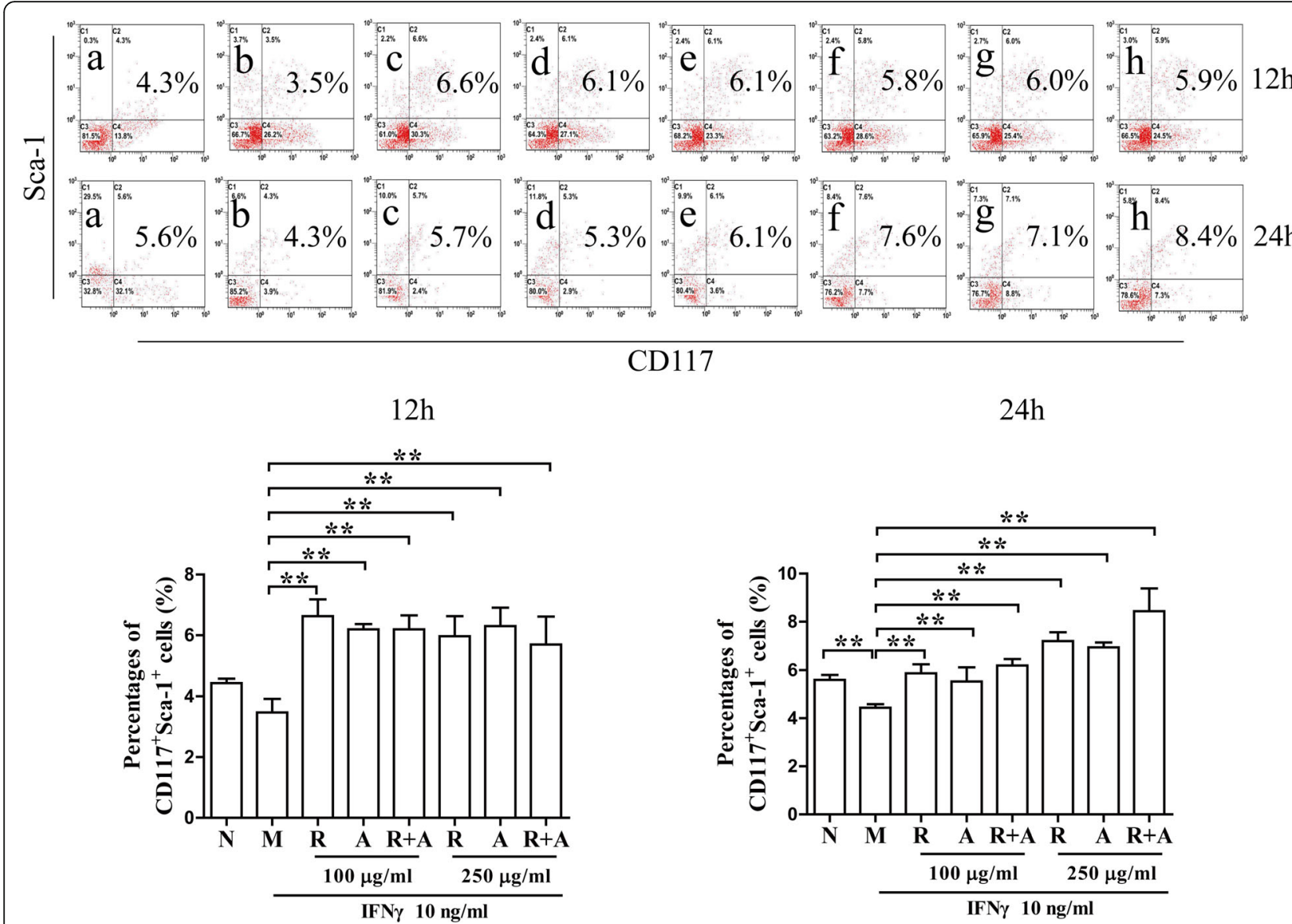

Fig. 2 Effects on the proliferation of CD $117^{+} \mathrm{SCa}-1^{+} \mathrm{HSCS}$ in IFN- $\gamma$-induced BM cells after 12 and $24 \mathrm{~h}$ of treatment. The results are presented in bar charts. a, Normal (N) group; b, Model (M) group; c and f, Radix Astragali (R) group; d and g, Radix Angelicae Sinensis (A) group; e and h, Radix Astragali + Radix Angelicae Sinensis $(R+A)$ group; $c, d$ and e were treated with $100 \mu \mathrm{g} / \mathrm{mL}$ of freeze-dried powder and $f, g$ and $h$ were treated with $250 \mu \mathrm{g} / \mathrm{mL}$ of freeze-dried powders. The results are presented in a bar chart. Data are the presented as mean $\pm S D, n=3$. ${ }^{*} P<0.05$ and ${ }^{* *} P<0.01$

used for data processing and statistical analysis. A $P<$ 0.05 was considered statistically significant.

\section{Results}

\section{Characteristics of compounds in freeze-dried water extract by HPLC-ESI/MS ${ }^{\mathrm{n}}$}

Seven constituents of Radix Astragali (Fig. 1a) and six constituents of Radix Angelicae Sinensis (Fig. 1b) were identified based on the target peaks. The identified compounds in the freeze-dried powders of aqueous extracts from these to herbs are shown in Tables 1 and 2.

Effects of Radix Astragali, Radix Angelicae Sinensis and the combination of both on the proliferation of HSCs in IFN$\mathrm{\gamma}$-induced BM cells

CD117 (c-Kit) and Ly-6A/E (Sca-1) are the cell membrane markers for HSCs [26]. Cells double-stained by CD117 and Sca-1 were assessed through flow cytometry. As shown in Fig. 2, the percentages of HSCs in the model group after 12 $\mathrm{h}$ or $24 \mathrm{~h}$ of induction by IFN- $\gamma$ decreased significantly compared with those in the normal group $(P<0.01)$. The percentages of HSCs in the treatment groups were increased significantly compared with those in the model group after $12 \mathrm{~h}$ or $24 \mathrm{~h}$ of treatment $(P<0.01)$. There was no significant difference between the two concentrations $(100 \mu \mathrm{g} / \mathrm{mL}$ and $250 \mu \mathrm{g} / \mathrm{mL}$ ) of herbs after $12 \mathrm{~h}$ of treatment. Interestingly, the percentage of HSCs in the $250 \mu \mathrm{g} / \mathrm{mL}$ concentration group after $24 \mathrm{~h}$ of treatment increased significantly more than that of the other groups. These results indicate that the synergistic effect of the combination of the two herbs on hematopoiesis was superior to that of a single herb alone. This effect showed significant time and dose dependence.

The proliferation and differentiation of $\mathrm{CD}^{+} \mathrm{T}$ cells in $\mathrm{BM}$ cells after treatment

As shown in Fig. 3, the percentages of $\mathrm{CD}^{+} \mathrm{CD}^{+} \mathrm{T}$ cells were not significantly different among the groups after $12 \mathrm{~h}$ of treatment. The levels of cellular proliferation in the treatment groups after $24 \mathrm{~h}$ of treatment were significantly higher than those in the other groups $(P<$ 


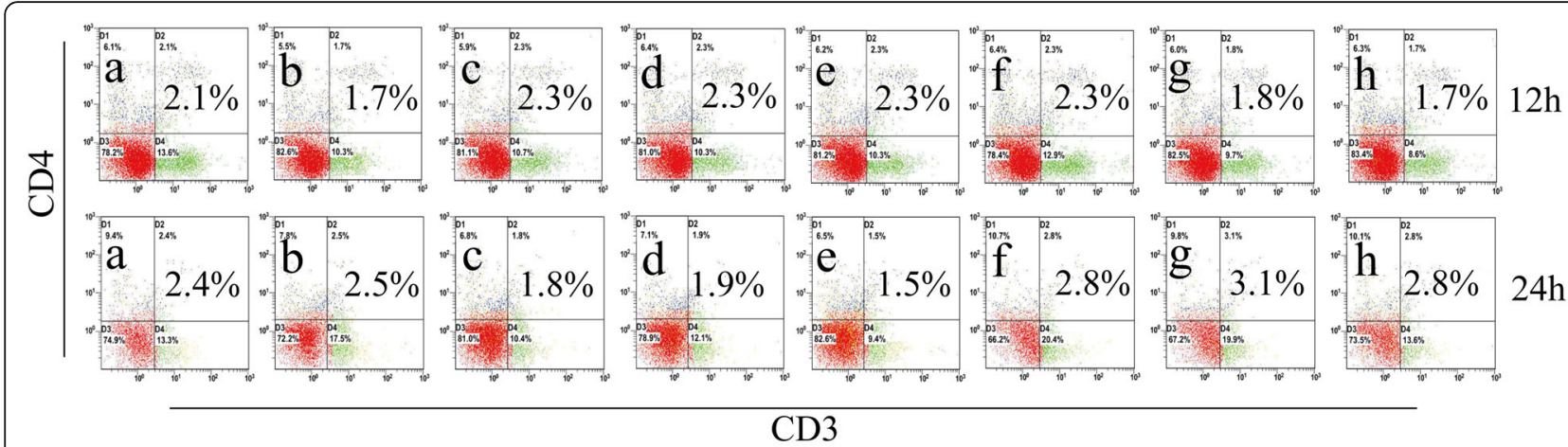

$12 \mathrm{~h}$

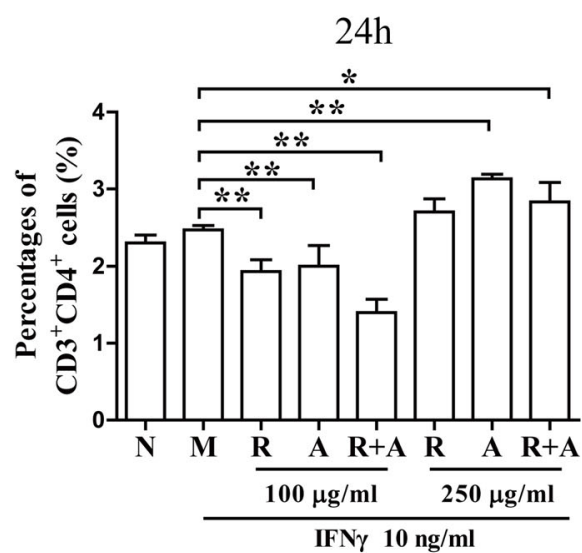

Fig. 3 Effects on the proliferation of $\mathrm{CD}^{+} \mathrm{CD}^{+} \mathrm{T}$ cells in BM cells after 12 and $24 \mathrm{~h}$ of treatment. The results are presented in bar charts. a, Normal (N) group; b, Model (M) group; c and f, Radix Astragali (R) group; d and g, Radix Angelicae Sinensis (A) group; e and h, Radix Astragali + Radix Angelicae Sinensis ( $+A$ ) group; $c$, d and e were treated with $100 \mu \mathrm{g} / \mathrm{mL}$ of freeze-dried powders, and f, $g$ and $\mathrm{h}$ were treated with $250 \mu \mathrm{g} /$ $\mathrm{mL}$ of freeze-dried powders. The results are presented in a bar chart. Data are presented as the mean $\pm \mathrm{SD}, n=3 .{ }^{*} P<0.05$ and ${ }^{* *} P<0.01$

0.05 or $P<0.01)$. However, treatment with RA or RAS decreased the IFN- $\gamma$-induced abnormal proliferation of $\mathrm{CD}^{+} \mathrm{CD}^{+}$cytotoxic $\mathrm{T}$ cells in BM cells. The inhibitory effect of Radix Astragali was better than that of Radix Angelicae Sinensis, and the synergistic effect of the combination of the two herbs was superior to that of a single herb alone (Fig. 4).

\section{Regulation of the SLAM/SAP signaling pathway activation by herbal treatment}

The activation of SLAM signaling pathway contribute to the proliferation and differentiation of $\mathrm{T}$ cells. The binding of SLAM and SAP transmits signaling to Fyn, inhibits the production of IFN- $\gamma$ in BM cells [27]. After $12 \mathrm{~h}$ of treatment, SAP/SLAM double-stained cells were significantly increased in the treatment groups compared with those in the model group $(P<0.01)$ (Fig. 5). The regulatory effect of Radix Astragali in the $100 \mu \mathrm{g} / \mathrm{mL}$ concentration group after $12 \mathrm{~h}$ of treatment increased significantly more than the in other groups. However, there was no significant difference between the groups after $24 \mathrm{~h}$ of treatment (Fig. 6).
Interference in the expression and distribution of T-bet in BM cells by herbal treatment

T-bet is the Th1-specific transcription factors. It binds to the gene promoter of IFN- $\gamma$, contributes to the IFN- $\gamma$ gene expression [28]. As shown in . 7, T-bet-stained cells were significantly increased in BM cells of the model group compared with that in the normal group after 12 $\mathrm{h}$ of treatment $(P<0.05)$. Both Radix Astragali and Radix Angelicae Sinensis significantly inhibited the IFN$\gamma$-induced expression and distribution of $\mathrm{T}$-bet in BM cells. Interestingly, the distribution of T-bet in the combination groups after $24 \mathrm{~h}$ of treatment decreased significantly more than in the other groups $(P<0.01)$ (Fig. 8). These results indicate that the synergistic effect of the two-herb combination was superior to that of herb alone, and showed significant time and dose dependence.

\section{Interference in IFN- $\gamma$-induced the activation of elF2a signaling pathway in BM cells}

The activation of eIF2 can downregulate the protein synthesis of BM cells under condition of several stresses [29]. The levels of eIF $2 \alpha$ and phospho-eIF $2 \alpha$ increased significantly compared with those of the normal group 


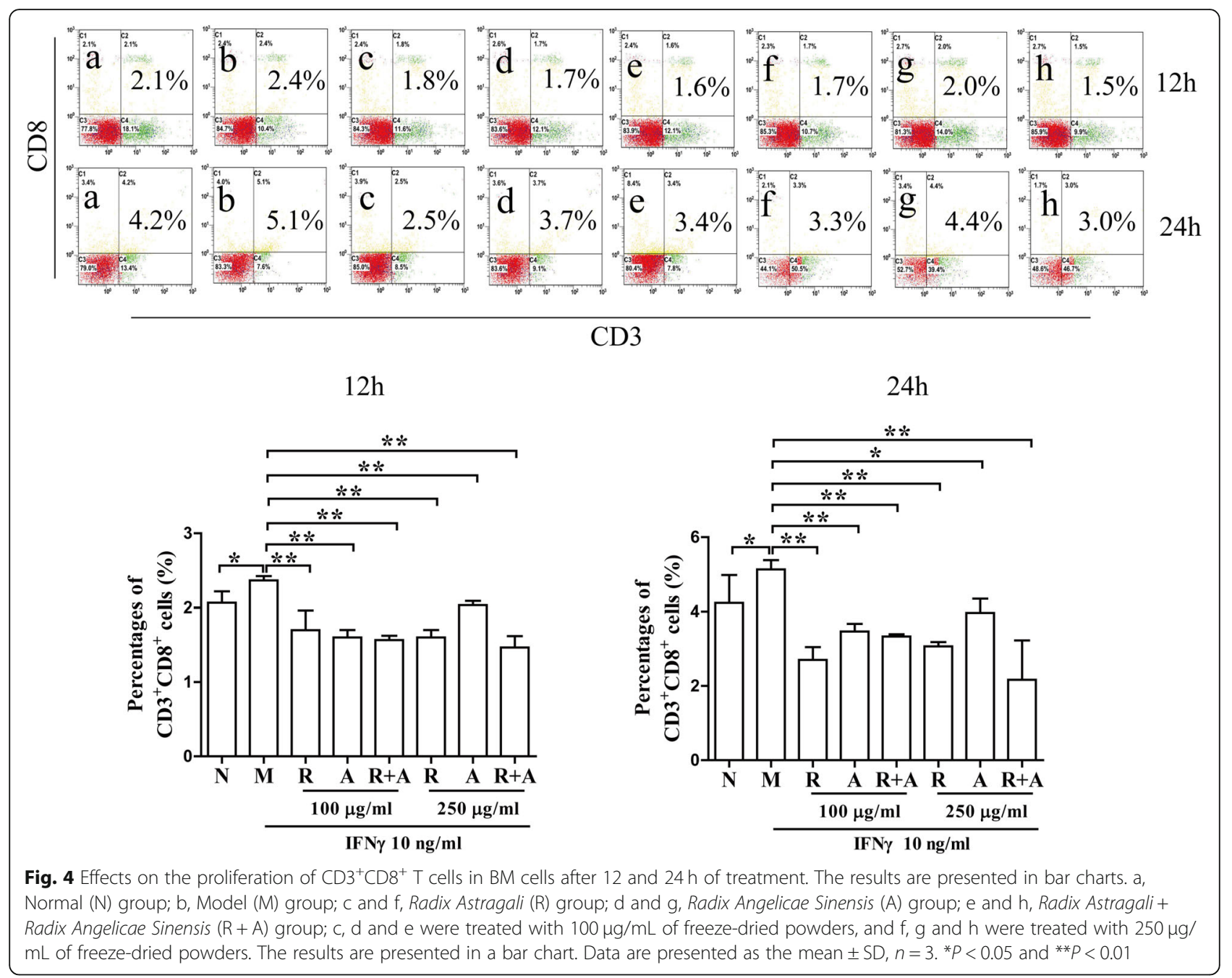

$(P<0.01$ or $P<0.05$, respectively). The phosphorylation level of eIF $2 \alpha$ in the treatment groups decreased significantly compared with that of the model group $(P<0.01)$. These findings indicate that both Radix Astragali and Radix Angelicae Sinensis could inhibit activation of the eIF2 $\alpha$ signaling pathway. The synergistic effect of the two-herb combination was superior to that of a single herb alone (Figs. 9 and 10).

\section{Discussion}

Herbal combinations, based on the herbal compatibility theory in traditional Chinese medicine (TCM), can enhance the therapeutic efficacy of a single herb [30]. Synergistic effects between Radix Astragali and Radix Angelicae Sinensis in DBT have been well illustrated [5]. Quality control of herbal combination is a precondition for cell experimental stability and reliability. Quality control of herbal combination is a precondition for cell experimental stability and reliability. HPLC-MS is an essential technology for the analysis of herbal constituents.
HPLC-ESI/MS ${ }^{\mathrm{n}}$ analysis identified seven Radix Astragali and six Radix Angelicae Sinensisconstituents in water extract of the herbs. Calycosin and formononetin, the major compounds in Radix Astragali, can promote cell adhesion [31], induce the expression of erythropoietin in kidney and liver cells [32] and regulate the activation of anti-oxidative enzymes [33]. Ferulic acid, the main component in Radix Angelicae Sinensis, can promote the proliferation of HSCs and hematopoietic function of bone marrow [34-36]. Based on pharmacological research, we hypothesized that the combination of Radix Astragali and Radix Angelicae Sinensis could attenuate immune attack on BM cells induced by pro-inflammatory cytokinesand the hematopoietic function of bone marrow. In this study, we also aimed to validate the synergistic effects of herbal compatibility.

Decreased numbers of IFN- $\gamma$-producing lymphocytes have been associated with hematologic improvement following immunosuppression in patients with hypoplastic myelodysplasia [1]. IFN- $\gamma$, secreted by activated T cells 


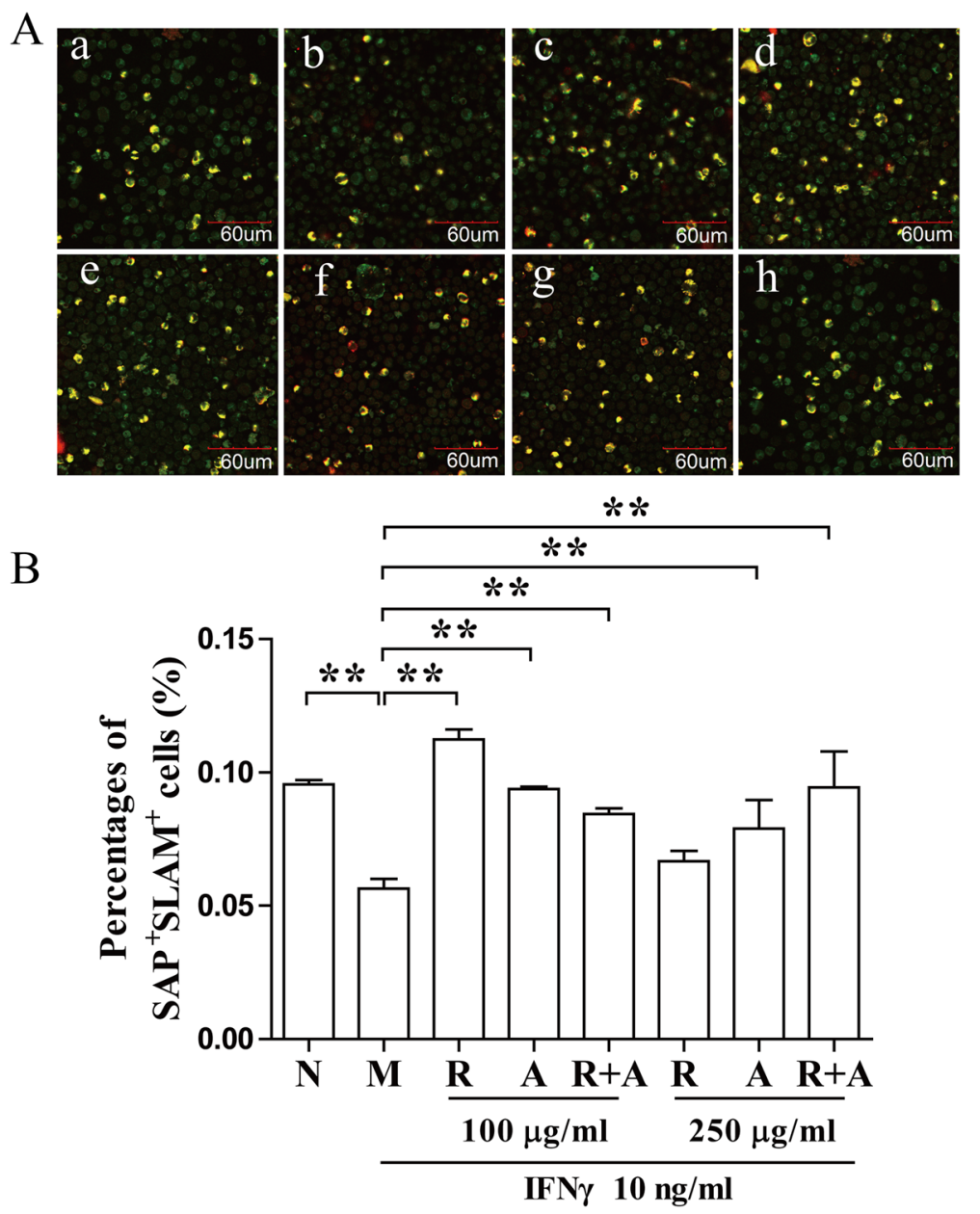

Fig. 5 Regulation of activation of the SLAM/SAP signaling pathway after $12 \mathrm{~h}$ of treatment. (a) BM cells were stained with CD150/SLAM and SH2D1A/SAP antibodies and observed by confocal immunofluorescence microscopy. The double-stained cells (yellow) were quantified with ImageJ. The scale bar corresponds to $60 \mu \mathrm{m}$ throughout. (b) The quantified results are presented in a bar chart. a, Normal (N) group; b, Model (M) group; c and f, Radix Astragali (R) group; d and g, Radix Angelicae Sinensis (A) group; e and h, Radix Astragali + Radix Angelicae Sinensis (R+A) group; $c, d$ and e were treated with $100 \mu \mathrm{g} / \mathrm{mL}$ of freeze-dried powders, and $\mathrm{f}, \mathrm{g}$ and h were treated with $250 \mathrm{\mu g} / \mathrm{mL}$ of freeze-dried powders. Data are presented as the mean $\pm \mathrm{SD}, n=3 .{ }^{*} P<0.05$ and ${ }^{* *} P<0.01$

in the BM, also has a profound impact on the hematopoietic system. IFN- $\gamma$ can suppress the formation of several hematopoietic lineages including B cells [37], erythrocytes [38], eosinophils [39] and neutrophilic granulocytes [40], resulting in increased cell death of hematopoietic progenitors by inducing cell apoptosis [41, 42]. The levels of IFN- $\gamma$ and TNF- $\alpha$ were increased significantly in bone marrow and peripheral blood of patients with aplastic anemia. Increased IFN- $\gamma$ and TNF- $\alpha$ can induce apoptosis of HSCs directly, promote the expression of Fas antigen on the surface of $\mathrm{CD} 34^{+}$cells in the bone marrow microenvironment, induce HSC apoptosis, and then inhibit the hematopoietic function of bone marrow [43, 44]. Our results showed that Radix Angelicae Sinensis treatment at high concentrations could increase the proliferation of HSCs in bone marrow after immune destruction. The synergistic effect of Radix Astragali and Radix
Angelicae Sinensis in combination on hematopoiesis was superior to that of a single herb alone.

T lymphocytes from AA patients cocultured with bone marrow cells were able to suppress hematopoiesis in vitro [45]. Oligoclonally expanded cytotoxic $\mathrm{T}$ cells (targeting hematopoietic stem and progenitor cells) and activated $\mathrm{CD}^{+} \mathrm{T}$ cells were identified as the lymphocyte s subsets that inhibited hematopoiesis in the bone marrow microenvironment. Removing the lymphocytes from bone marrow could improve colony numbers in tissue culture. Specific $\mathrm{CD} 8^{+} \mathrm{CD} 28^{-}$cell clones are expanded in AA peripheral blood, and oligo-clones recognize and induce apoptosis of autologous myeloid cells [46]. Our results indicated that both Radix Astragali and Radix Angelicae Sinensis could regulate the proliferation and differentiation of $\mathrm{T}$ cells. The two herbs could downregulate the levels of $\mathrm{CD}^{+} \mathrm{CD}^{+} \mathrm{T}$ cells at low 


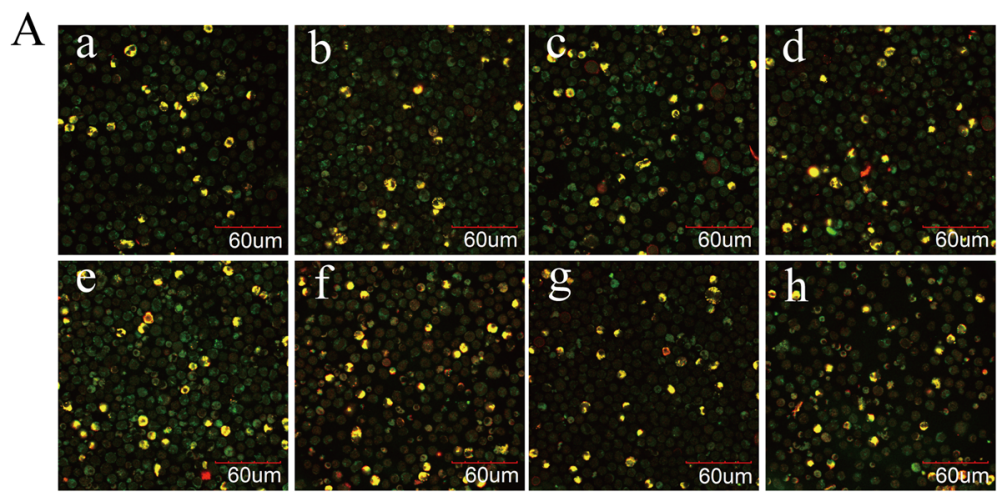

B

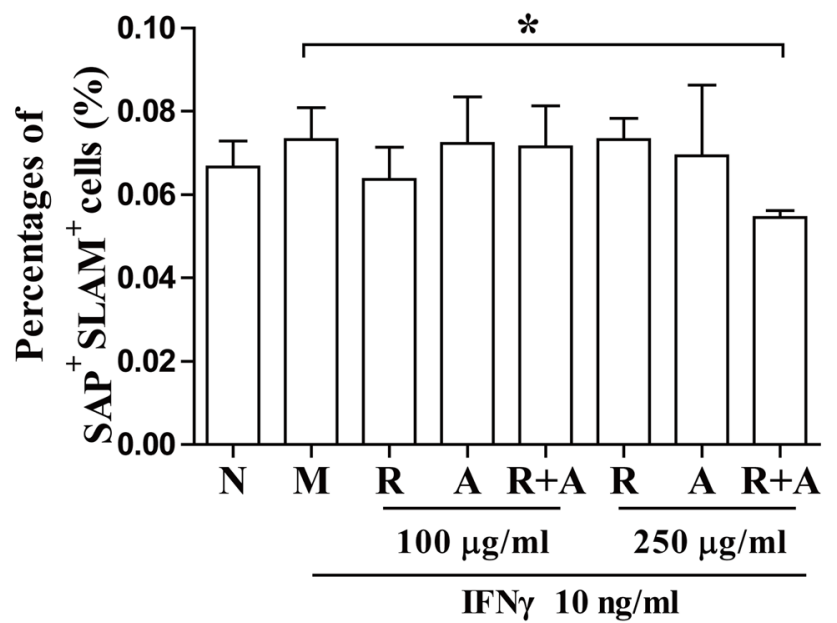

Fig. 6 Regulation of activation of the SLAM/SAP signaling pathway after $24 \mathrm{~h}$ of treatment. (a) BM cells were stained with CD150/SLAM and SH2D1A/SAP antibodies and observed by confocal immunofluorescence microscopy. The double-stained cells (yellow) were quantified with ImageJ. The scale bar corresponds to $60 \mu \mathrm{m}$ throughout. (b) The quantified results are presented in a bar chart. a, Normal (N) group; b, Model (M) group; $\mathrm{c}$ and f, Radix Astragali (R) group; $d$ and g, Radix Angelicae Sinensis (A) group; e and h, Radix Astragali + Radix Angelicae Sinensis (R + A) group; c, d and e were treated with $100 \mu \mathrm{g} / \mathrm{mL}$ of freeze-dried powders, and f, $g$ and $\mathrm{h}$ were treated with $250 \mu \mathrm{g} / \mathrm{mL}$ of freeze-dried powders. Data are presented as the mean $\pm S D, n=3 .{ }^{*} P<0.05$ and ${ }^{* *} P<0.01$

concentrations. However, the percentages of $\mathrm{CD}^{+} \mathrm{CD} 4^{+}$ $\mathrm{T}$ cells were upregulated after $24 \mathrm{~h}$ of treatment at high concentrations. The herbal treatment also inhibited the abnormal proliferation of $\mathrm{CD}^{+} \mathrm{CD}^{+} \mathrm{T}$ cells. The combination of the two herbs showed greater synergistic effects compared with that of either herb alone. These effects had a significant dose-effect relationship.

$\mathrm{T}$-bet binding to the IFN- $\gamma$ promoter region is critical for Th1 polarization. T-bet can be upregulated in the T cells of patients with AA. T-bet binds to the promoter region of the IFN- $\gamma$ gene and stimulates the protein expression of IFN- $\gamma$. CD150 combined with SLAM can bind to the signal molecule SAP and modulate the function of SLAM in IFN- $\gamma$ production in hematopoietic cells [47, 48]. The freeze-dried water extract of Radix Angelicae Sinensis could significantly decreased the expression of T-bet after $12 \mathrm{~h}$ of treatment. Radix Astragali significantly increased the number of SLAM/SAP double-stained cells after $12 \mathrm{~h}$ of treatment at low concentrations. The synergistic effect of the combination of the Radix Astragali and Radix Angelicae Sinensis was better than that of other groups at high concentrations Based on these results, we considered that the combination of these two herbs could interfere with the expression of T-bet and the binding of SAP and Fyn to inhibit the function of IFN- $\gamma$, contributing to restoring the hematopoietic function of BM cells.

IFN- $\gamma$ can activate IRF-1, induce the activation of PRK/eIF2 signaling pathways, interfere in gene transcription, protein synthesis and periodic cell division, and inhibit the proliferation of HSCs. Treatment with Radix Astragali and Radix Angelicae Sinensis could regulate the protein expression and phosphorylation of eIF2 $\alpha$. The regulatory effect of Radix Angelicae Sinensis at high concentrations was better than that of Radix Astragali. The synergistic effects of the combination of the two 
A
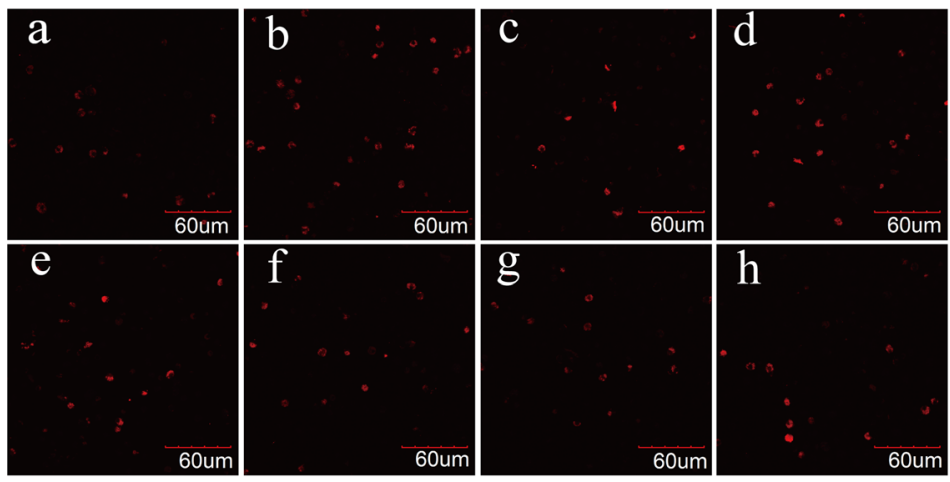

B

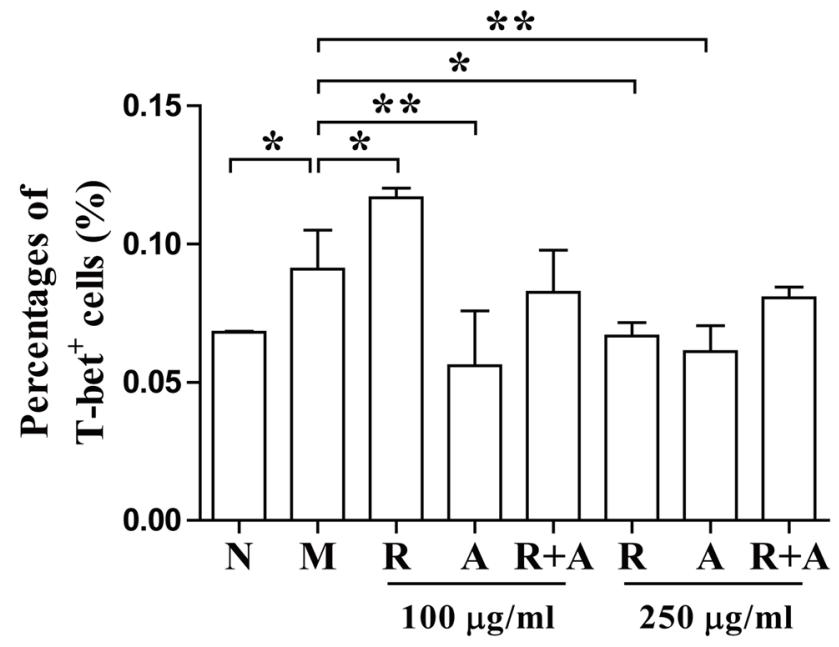

IFN $10 \mathrm{ng} / \mathrm{ml}$

Fig. 7 Interference in the expression and distribution of T-bet in BM cells after $12 \mathrm{~h}$ of treatment. (a) Staining for T-bet (red) in BM cells was observed by confocal immunofluorescence microscopy. The stained cells (red) were quantitated with ImageJ. The scale bar corresponds to $60 \mu \mathrm{m}$ throughout. (b) The quantified results are presented in a bar chart. a, Normal (N) group; b, Model (M) group; c and f, Radix Astragali (R) group; d and g, Radix Angelicae Sinensis (A) group; e and h, Radix Astragali + Radix Angelicae Sinensis (R+A) group; c, d and e were treated with $100 \mu \mathrm{g} / \mathrm{mL}$ of freeze-dried powders and $\mathrm{f}, \mathrm{g}$ and $\mathrm{h}$ were treated with $250 \mu \mathrm{g} / \mathrm{mL}$ of freeze-dried powders. Data are presented as the mean $\pm S D, n=3$. ${ }^{*} P<$ 0.05 and ${ }^{* *} P<0.01$

herbs were better than those of a single herb alone after $12 \mathrm{~h}$ and $24 \mathrm{~h}$ of treatment. These results indicated that PRK/eIF2 signaling pathways could also be one of the important targets for the synergistic hemopoietic stimulating function of the combination of Radix Astragali and Radix Angelicae Sinensis.

Compatibility of Chinese herbs, which compose TCM formulas, can achieve synergistic therapeutic effects. However, the therapeutic mechanisms and targets of compatibility of Chinese herbs have not yet been identified. Our results indicate that the therapeutic function of Radix Astragali focused on suppressing immune inflammation while that of Radix Angelicae Sinensis focused on repairing the immune destruction of BM cells. The combination of the two herbs could attenuate the immune destruction of hematopoiesis in BM cells induced by pro-inflammatory cytokines, achieving a synergetic effect based on TCM compatibility theory. The results of herbal composition analysis also provided other relevant evidence.

\section{Conclusions}

In summary, our results indicated that the combination of Radix Astragali and Radix Angelicae Sinensis could reduce the proliferation and differentiation of effector $\mathrm{T}$ cells, restore the balance of the $\mathrm{T}$ cell immune response network and recover the hematopoietic function of HSCs. The main mechanisms likely involve inhibiting the IFN- $\gamma$-induced expression of $\mathrm{T}$-bet in the bone marrow microenvironment, intervening in the activation of the eIF2 signaling pathway, attenuating immune-mediated destruction of HSCs induced by pro-inflammatory 


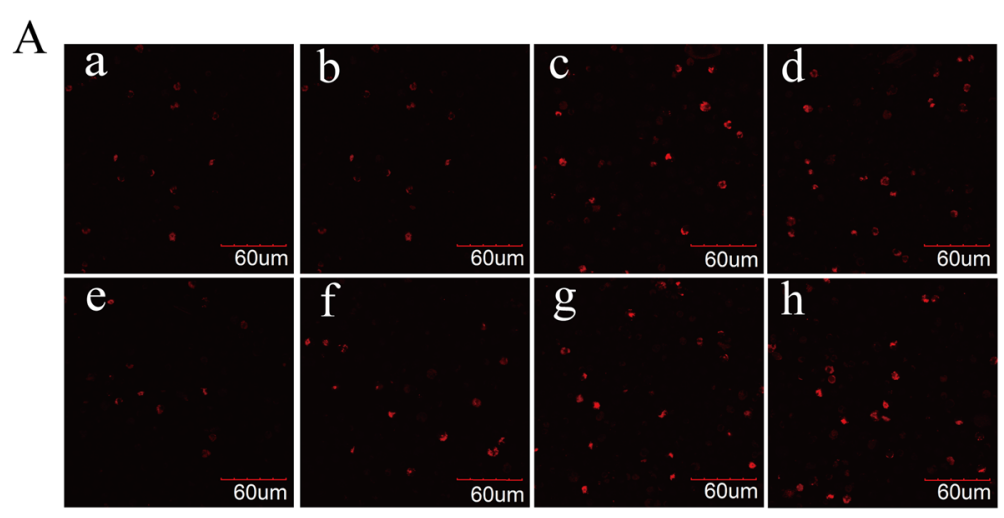

$\mathrm{B}$

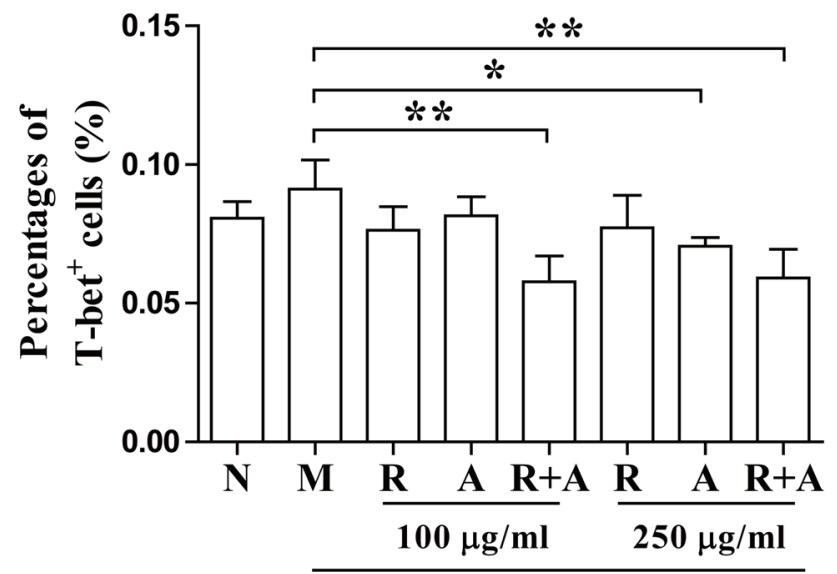

IFNy $10 \mathrm{ng} / \mathrm{ml}$

Fig. 8 Interference in the expression and distribution of T-bet in BM cells after $24 \mathrm{~h}$ of treatment. Staining for T-bet (red) in BM cells was observed by confocal immunofluorescence microscopy. The stained cells (red) were quantitated with Image J. The scale bar corresponds to $60 \mu \mathrm{m}$ throughout. (b) The quantified results are presented in a bar chart. a, Normal (N) group; b, Model (M) group; c and f, Radix Astragali (R) group; $d$ and g, Radix Angelicae Sinensis (a) group; e and h, Radix Astragali + Radix Angelicae Sinensis ( + A) group; $c$, d and e were treated with $100 \mathrm{\mu g} / \mathrm{mL}$ of freeze-dried powders and $\mathrm{f}, \mathrm{g}$ and $\mathrm{h}$ were treated with $250 \mu \mathrm{g} / \mathrm{mL}$ of freeze-dried powders. Data are presented as the mean $\pm S D, n=3$. ${ }^{*} P<$ 0.05 and ${ }^{* *} P<0.01$ 


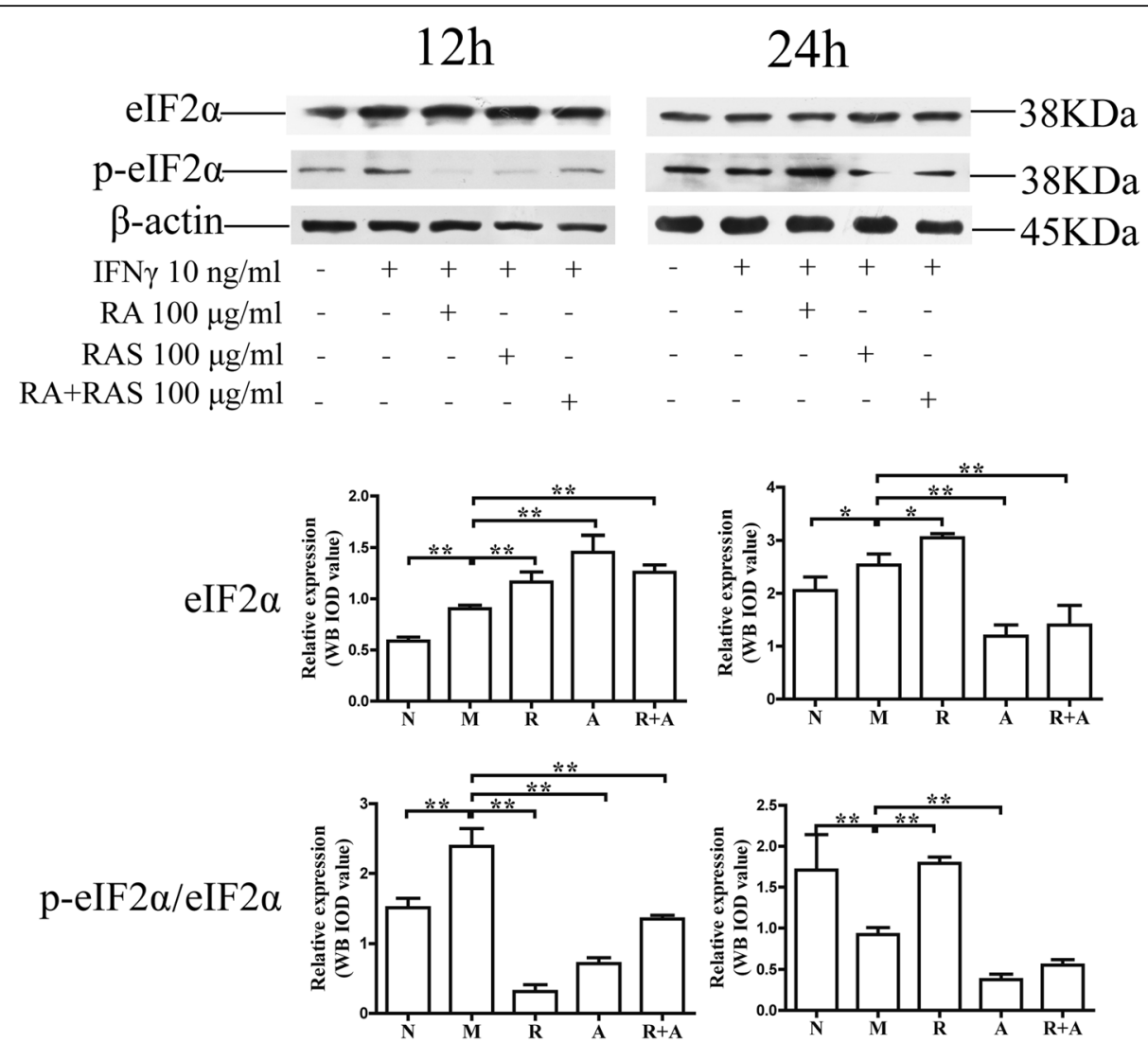

Fig. 9 Interference in the levels of phospho-elF2a in BM cells at $100 \mu \mathrm{g} / \mathrm{mL}$ of Radix Astragali and Radix Angelicae Sinensis treatment. The expression levels of elF2 $a$ and phospho-elF2 $a$ in BM cells were determined by Western blot analysis. $\beta$-actin was used as an internal control. The quantified results are presented in a bar chart. Data are presented as the mean $\pm \mathrm{SD}, n=3 .{ }^{*} P<0.05$ and ${ }^{* *} P<0.01$ 


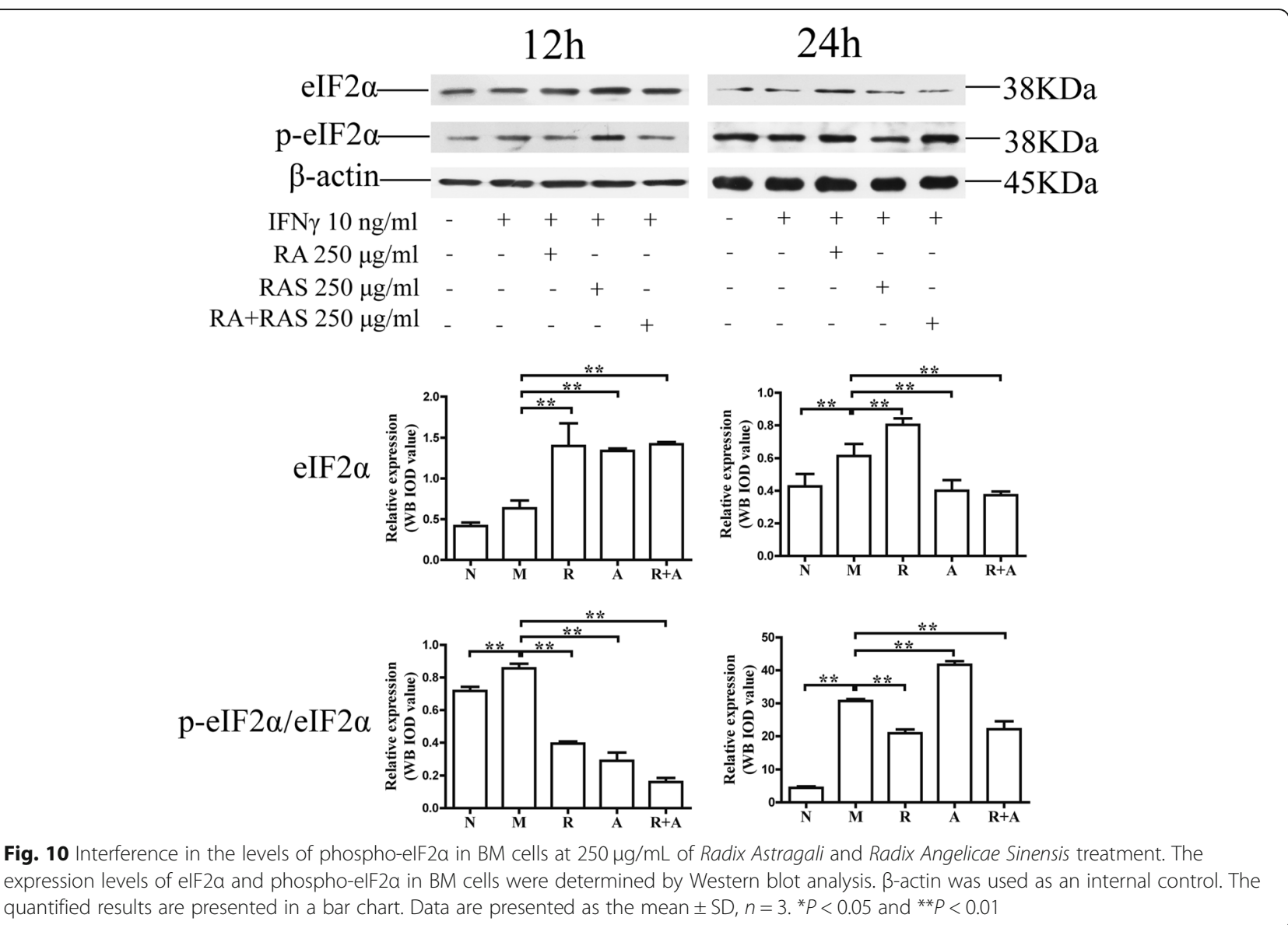


cytokines. Prolonged stimulation at high concentrations of combined Radix Astragali and Radix Angelicae Sinensis on marrow failure induced by immune attack showed improved therapeutic effect. The synergistic effect of the combination of these two herbs was superior to that of a single herb alone.

\section{Supplementary information}

Supplementary information accompanies this paper at https://doi.org/10. 1186/s12906-019-2781-4

Additional file $\mathbf{1}$ Inspection reports of Radix Astragali and Radix Angelicae Sinensis.

Additional file 2: Figure. S1. The cell viability of Bone marrow cells treated by RAS (A) and RA (B). Results were presented in a bar chart. Data were presented as mean $\pm \mathrm{SD}, n=3$.

\section{Abbreviations}

AA: Aplastic anemia; BM: Bone marrow; DBT: Danggui buxue tang; HPLC-ESI/ $M^{n}$ : High-performance liquid chromatography-electrospray ionization/mass spectrometer; HSCs: Hematopoietic stem cells; IFN: Interferon; IRF: Interferon regulatory factor; OD: Optical density; RA: Radix astragali; RAS: Radix angelicae sinensis.: S.D.: Standard deviation

\section{Acknowledgements}

The authors thank Dr. Yanbo Jia for HPLC-ESI/MS ${ }^{n}$ technical assistance.

\section{Authors' contributions}

$J \mathrm{~L}, \mathrm{JW}, \mathrm{CW}, \mathrm{XM}$ and $\mathrm{HC}$ carried out the experiments and analyzed the constituents of Radix Astragali and Radix Angelicae Sinensis. These five authors contributed equally to this work. $\mathrm{PD}, \mathrm{MH}, \mathrm{HZ}$, and $\mathrm{XL}$ participated in the experiments and discussed the results. LC participated in overall experiments, designed and coordinated the study and drafted the manuscript. All authors read and approved the final manuscript.

\section{Funding}

This work was supported by the Special Project of the National Clinical Research Base of Traditional Chinese Medicine [JDZX2015191]. The funding body has not participated in the design of the study in collection, analysis, and interpretation of data and in writing the manuscript.

\section{Availability of data and materials}

The datasets used and/or analyzed during the current study are available from the corresponding author upon a reasonable request. All data generated or analyzed during this study are included in this published article and its supplementary information files.

\section{Ethics approval and consent to participate}

In this study, animal care and use were in accordance with institutional guidelines, and all animal experiments were approved by the Institutional Animal Care and Use Committee of the National Institute of state Scientific and Technological Commission [No. SYXK (Jing) 2015-001]

\section{Consent for publication}

Not applicable.

\section{Competing interests}

The authors declare that they have no competing interests.

\section{Author details}

${ }^{1}$ Key Laboratory of Chinese Internal Medicine of Ministry of Education and Beijing, Dongzhimen Hospital, Beijing University of Chinese Medicine, Haiyuncang Hutong No.5, Dongcheng District, Beijing, China. ${ }^{2}$ Department of Rheumatology, The Second Affiliated Hospital of GuangZhou University of Chinese Medicine, GuangZhou, China.
Received: 16 July 2019 Accepted: 29 November 2019

Published online: 09 December 2019

\section{References}

1. de Bruin AM, Voermans C, Nolte MA. Impact of interferon-gamma on hematopoiesis. Blood. 2014;124(16):2479-86

2. Dufour C, Corcione A, Svahn J, Haupt R, Poggi V, Beka'ssy AN, Scime R, Pistorio A, Pistoia V. TNF-alpha and IFN-gamma are overexpressed in the bone marrow of Fanconi anemia patients and TNF-alpha suppresses erythropoiesis in vitro. Blood. 2003;102(6):2053-9.

3. de Bruin AM, Demirel O, Hooibrink B, Brandts $\mathrm{CH}$, Nolte MA. Interferongamma impairs proliferation of hematopoietic stem cells in mice. Blood. 2013;121(18):3578-85.

4. Solomou EE, Keyvanfar K, Young NS. T-bet, a Th1 transcription factor, is upregulated in T cells from patients with aplastic anemia. Blood. 2006;107(10): 3983-91.

5. $\quad$ Lin HQ, Gong AG, Wang HY, Duan R, Dong TT, Zhao KJ, Tsim KW. Danggui Buxue tang (Astragali Radix and Angelicae Sinensis Radix) for menopausal symptoms: a review. J Ethnopharmacol. 2017;199:205-10.

6. Zheng KY, Choi RC, Xie HQ, Cheung AW, Guo AJ, Leung KW, Chen VP, Bi CW, Zhu KY, Chan GK, et al. The expression of erythropoietin triggered by danggui buxue tang, a Chinese herbal decoction prepared from radix Astragali and radix Angelicae Sinensis, is mediated by the hypoxia-inducible factor in cultured HEK293T cells. J Ethnopharmacol. 2010;132(1):259-67.

7. Choi RC, Gao QT, Cheung AW, Zhu JT, Lau FT, Li J, Li WZ, Chu GK, Duan R, Cheung JK, et al. A chinese herbal decoction, danggui buxue tang, stimulates proliferation, differentiation and gene expression of cultured osteosarcoma cells: genomic approach to reveal specific gene activation. Evid-Based Complementary Altern Med : eCAM. 2011;2011:307548.

8. Zhang WL, Zheng KY, Zhu KY, Zhan JY, Bi CW, Chen JP, Du CY, Zhao KJ, Lau DT, Dong TT, et al. Chemical and biological assessment of Angelica herbal decoction: comparison of different preparations during historical applications. Phytomedicine : Int J Phytother Phytopharmacology. 2012; 19(11):1042-8

9. Liu WJ. What has been overlooked on study of Chinese materia medica in the west? Chinese J Integr Med. 2015;21(7):483-92.

10. Jiao Y, Wen J, Yu X. Influence of flavonoid of Astragalus membranaceus's stem and leaves on the function of cell mediated immunity in mice. Zhongguo Zhong xi yi jie he za zhi Zhongguo Zhongxiyi jiehe zazhi = Chinese J Integr Tradit West Med. 1999, 19;(6):356-8.

11. Shi J, Zheng L, Lin Z, Hou C, Liu W, Yan T, Zhu L, Wang Y, Lu L, Liu Z. Study of pharmacokinetic profiles and characteristics of active components and their metabolites in rat plasma following oral administration of the water extract of Astragali radix using UPLC-MS/MS. J Ethnopharmacol. 2015;169: 183-94.

12. Or PM, Lam FF, Kwan YW, Cho CH, Lau CP, Yu H, Lin G, Lau CB, Fung KP, Leung PC, et al. Effects of Radix Astragali and Radix Rehmanniae, the components of an anti-diabetic foot ulcer herbal formula, on metabolism of model CYP1A2, CYP2C9, CYP2D6, CYP2E1 and CYP3A4 probe substrates in pooled human liver microsomes and specific CYP isoforms. Phytomedicine: Int J Phytotherapy Phytopharmacology. 2012;19(6):535-44.

13. Wu J, Xu H, Zhang L, Zhang X. Radix Astragali and Tanshinone help carboplatin inhibit B16 tumor cell growth. Technol Cancer Res Treat. 2016; 15(4):583-8.

14. Dong TT, Ma XQ, Clarke C, Song ZH, Ji ZN, Lo CK, Tsim KW. Phylogeny of Astragalus in China: molecular evidence from the DNA sequences of $5 \mathrm{~S}$ rRNA spacer, ITS, and 18S rRNA. J Agric Food Chem. 2003;51(23):6709-14.

15. Gao J, Huang Y, Li P, Xu D, Li J, Liu Y, Huang Z, Wu Q, Shao X. Antifibrosis effects of total glucosides of Danggui-Buxue-tang in a rat model of bleomycin-induced pulmonary fibrosis. J Ethnopharmacol. 2011;136(1):21-6.

16. Yang X, Huang CG, Du SY, Yang SP, Zhang X, Liu JY, Xian Q, Xu JH. Effect of Danggui Buxue tang on immune-mediated aplastic anemia bone marrow proliferation mice. Phytomedicine : Int J Phytother Phytopharmacology. 2014;21(5):640-6.

17. Wang WL, Sheu SY, Chen YS, Kao ST, Fu YT, Kuo TF, Chen KY, Yao CH. Enhanced bone tissue regeneration by porous gelatin composites loaded with the Chinese herbal decoction Danggui Buxue tang. PLoS One. 2015; 10(6):e0131999.

18. Deng $\mathrm{P}$, Li X, Wei Y, Liu J, Chen M, Xu Y, Dong B, Zhu L, Chai L. The herbal decoction modified Danggui Buxue Tang attenuates immune-mediated 
bone marrow failure by regulating the differentiation of T lymphocytes in an immune-induced aplastic anemia mouse model 2017, 12(7):e0180417.

19. Zhou J, Li X. Chinese herbal formula, modified Danggui Buxue tang. Attenuates Apoptosis of Hematopoietic Stem Cells in Immune-Mediated Aplastic Anemia Mouse Model. 2017;2017:9786972.

20. Maciejewski J, Selleri C, Anderson S, Young NS. Fas antigen expression on CD34+ human marrow cells is induced by interferon gamma and tumor necrosis factor alpha and potentiates cytokine-mediated hematopoietic suppression in vitro. Blood. 1995;85(11):3183-90.

21. Chen JH, Kim SH, Fan PW, Liu CY, Hsieh CH, Fang K. The aqueous extract of Chinese medicinal herb Brucea javanica suppresses the growth of human liver cancer and the derived stem-like cells by apoptosis. Drug Des, Dev Ther. 2016;10:2003-13.

22. Lin S, Nie B, Song K, Ye R, Yuan Z. Pinelliae Rhizoma Praeparatum cum Alumine extract: sedative and hypnotic effects in mice and component compounds. Biomed Res Int. 2019;2019:6198067.

23. Li J, Wei Y, Li X, Zhu D, Nie B, Zhou J, Lou L, Dong B, Wu A, Che Y, et al. Herbal formula Xian-Fang-Huo-Ming-yin regulates differentiation of lymphocytes and production of pro-inflammatory cytokines in collageninduced arthritis mice. BMC Complement Altern Med. 2017;17(1):12.

24. Kent DG, Dykstra BJ, Eaves CJ. Isolation and Assessment of Single LongTerm Reconstituting Hematopoietic Stem Cells from Adult Mouse Bone Marrow. Curr Protoc Stem Cell Biol. 2016;38:2A 4 1-2A 424

25. Jiao X, Zhang S, Jiao J, Zhang T, Qu W, Muloye GM, Kong B, Zhang Q, Cui B. Promoter methylation of SEPT9 as a potential biomarker for early detection of cervical cancer and its overexpression predicts radioresistance. Clin Epigenetics. 2019;11(1):120.

26. Wang L, Zhou GB, Liu P, Song JH, Liang Y, Yan XJ, Xu F, Wang BS, Mao JH, Shen ZX, et al. Dissection of mechanisms of Chinese medicinal formula Realgar-indigo naturalis as an effective treatment for promyelocytic leukemia. Proc Natl Acad Sci U S A. 2008;105(12):4826-31.

27. Yang M, Chan GC, Deng R, Ng MH, Cheng SW, Lau CP, Ye JY, Wang L, Liu C. An herbal decoction of Radix astragali and Radix angelicae sinensis promotes hematopoiesis and thrombopoiesis. J Ethnopharmacol. 2009; 124(1):87-97.

28. Gao QT, Cheung JK, Choi RC, Cheung AW, Li J, Jiang ZY, Duan R, Zhao KJ Ding AW, Dong TT, et al. A Chinese herbal decoction prepared from Radix Astragali and Radix Angelicae Sinensis induces the expression of erythropoietin in cultured Hep3B cells. Planta Med. 2008;74(4):392-5.

29. Hendrick HM, Welter BH, Hapstack MA, Sykes SE, Sullivan WJ Jr, Temesvari LA. Phosphorylation of eukaryotic initiation factor-2alpha during stress and encystation in Entamoeba species. PLoS Pathog. 2016;12(12):e1006085.

30. Pan SY, Chen SB, Dong HG, Yu ZL, Dong JC, Long ZX, Fong WF, Han YF, Ko KM. New perspectives on chinese herbal medicine (zhong-Yao) research and development. Evid-Based Complement Altern Med : eCAM. 2011;2011: 403709

31. Nasr Bouzaiene N, Kilani Jaziri S, Kovacic H, Chekir-Ghedira L, Ghedira K, Luis J. The effects of caffeic, coumaric and ferulic acids on proliferation, superoxide production, adhesion and migration of human tumor cells in vitro. Eur J Pharmacol. 2015;766:99-105.

32. Zheng KY, Choi RC, Cheung AW, Guo AJ, Bi CW, Zhu KY, Fu Q, Du Y, Zhang WL, Zhan JY, et al. Flavonoids from Radix Astragali induce the expression of erythropoietin in cultured cells: a signaling mediated via the accumulation of hypoxia-inducible factor-1alpha. J Agric Food Chem. 2011;59(5):1697-704.

33. Yu DH, Bao YM, An LJ, Yang M. Protection of PC12 cells against superoxideinduced damage by isoflavonoids from Astragalus mongholicus. Biomed Environ Sci : BES. 2009;22(1):50-4.

34. Andrade CM, Sa MF, Toloi MR. Effects of phytoestrogens derived from soy bean on expression of adhesion molecules on HUVEC. Climacteric : J Int Menopause Soc. 2012;15(2):186-94.

35. Ma ZC, Hong Q, Wang YG, Tan HL, Xiao CR, Liang QD, Lu BB, Gao Y. Effects of ferulic acid on hematopoietic cell recovery in whole-body gamma irradiated mice. Int J Radiat Biol. 2011;87(5):499-505.

36. Yu H, Zhang WL, Ding X, Zheng KY, Ho CM, Tsim KW, Lee YK. Optimizing combinations of flavonoids deriving from astragali radix in activating the regulatory element of erythropoietin by a feedback system control scheme. Evid-Based Complement Altern Med : eCAM. 2013;2013:541436.

37. Arens $R$, Tesselaar K, Baars PA, van Schijndel GM, Hendriks J, Pals ST, Krimpenfort P, Borst J, van Oers MH, van Lier RA. Constitutive CD27/CD70 interaction induces expansion of effector-type $T$ cells and results in IFNgamma-mediated B cell depletion. Immun. 2001;15(5):801-12.
38. Libregts SF, Gutierrez L, de Bruin AM, Wensveen FM, Papadopoulos P, van ljcken W, Ozgur Z, Philipsen S, Nolte MA. Chronic IFN-gamma production in mice induces anemia by reducing erythrocyte life span and inhibiting erythropoiesis through an IRF-1/PU.1 axis. Blood. 2011;118(9):2578-88.

39. de Bruin AM, Buitenhuis $M$, van der Sluijs KF, van Gisbergen KP, Boon L, Nolte MA. Eosinophil differentiation in the bone marrow is inhibited by $T$ cell-derived IFN-gamma. Blood. 2010;116(14):2559-69.

40. de Bruin AM, Libregts SF, Valkhof M, Boon L, Touw IP, Nolte MA. IFNgamma induces monopoiesis and inhibits neutrophil development during inflammation. Blood. 2012;119(6):1543-54.

41. Qin Y, Zhang C. The Regulatory Role of IFN-gamma on the Proliferation and Differentiation of Hematopoietic. Stem and Progenitor Cells. 2017;13(6):705-12.

42. Smith JNP, Zhang Y, Li JJ, McCabe A, Jo HJ, Maloney J, MacNamara KC. Type I IFNs drive hematopoietic stem and progenitor cell collapse via impaired proliferation and increased RIPK1-dependent cell death during shock-like ehrlichial infection. PLoS Pathog. 2018;14(8):e1007234.

43. Oh JE, Shim KY, Lee Jl, Choi SI, Baik SK, Eom YW. 1-methyl-L-tryptophan promotes the apoptosis of hepatic stellate cells arrested by interferongamma by increasing the expression of IFN-gammaRbeta, IRF-1 and FAS. Int J Mol Med. 2017:40(2):576-82.

44. Chen J, Feng X, Desierto MJ, Keyvanfar K, Young NS. IFN-gamma-mediated hematopoietic cell destruction in murine models of immune-mediated bone marrow failure. Blood. 2015;126(24):2621-31.

45. Smith JN, Kanwar VS, MacNamara KC. Hematopoietic stem cell regulation by type I and II Interferons in the pathogenesis of acquired aplastic Anemia. Front Immunol. 2016;7:330.

46. Schoettler ML, Nathan DG. The pathophysiology of acquired aplastic Anemia: current concepts revisited. Hematol Oncol Clin North Am. 2018; 32(4):581-94.

47. Chen S, Cai C, Li Z. Dissection of SAP-dependent and SAP-independent SLAM family signaling in NKT cell development and humoral immunity. J Exp Med. 2017;214(2):475-489.

48. Chen S, Dong Z. NK cell recognition of hematopoietic cells by SLAM-SAP families. Cell Mol Immunol. 2019;16(5):452-9.

\section{Publisher's Note}

Springer Nature remains neutral with regard to jurisdictional claims in published maps and institutional affiliations.

\section{Ready to submit your research? Choose BMC and benefit from:}

- fast, convenient online submission

- thorough peer review by experienced researchers in your field

- rapid publication on acceptance

- support for research data, including large and complex data types

- gold Open Access which fosters wider collaboration and increased citations

- maximum visibility for your research: over $100 \mathrm{M}$ website views per year

At BMC, research is always in progress.

Learn more biomedcentral.com/submissions 